\title{
ANALISIS GROWTH RATIO, RASIO EFEKTIVITAS DAN EFISIENSI PADA BADAN PENGELOLA PAJAK DAN RETRIBUSI DAERAH KOTA MEDAN
}

\author{
${ }^{1}$ Azizah Widyastuti Harahap, ${ }^{2}$ Mas'ut, ${ }^{3}$ Jalilah Ilmiha, ${ }^{4}$ Syamsul Effendi \\ $1,2,3,4$ Universitas Islam Sumatera Utara \\ Iazizahwidyastuti30@gmail.com, ${ }^{2}$ m.masut@yahoo.com, ${ }^{3}$ Jalilah.ilmiha@fe.uisu.ac.id, ${ }^{4}$ syamsul.effendi@fe.uisu.ac.id
}

\begin{abstract}
The definition of the financial performance of a region is the level of achievement of a work result in the regional financial sector. Measurement of the financial performance of local governments is carried out by examining the regional financial performance ratios as seen through the Medan City Regional Budget Realization Report. The ratios to assess the financial performance of local governments used in this study include: Growth Ratios, Effectiveness and Efficiency Ratios. This study aims to analyze the level of growth ratios, effectiveness and efficiency during the 2016-2019 period to see the financial performance of the Medan City Government. In writing this thesis using quantitative descriptive analysis method. The results of this study indicate that the financial performance of the Medan City Government by using a Growth Ratio is still not optimal because there was a significant decrease in 2018 due to a decrease in regional income in Medan City. The financial performance of Medan City as measured by the 2016 Effectiveness Ratio is categorized as quite effective, namely 84.82\%. In 2017, 2018, and 2019 were categorized as effective because they had a value above 90\%, namely 2017 amounting to 99.15\%, 2018 amounting to 92.88\%, and in 2019 amounting to $90.56 \%$. The financial performance of Medan City Government as measured by the Efficiency Ratio is categorized as very efficient because all results have a value below $60 \%$. $201610.35 \%, 2017$ 8.55\%, 2018 7.35\%, $20199.61 \%$.
\end{abstract}

Keywords: Growth Ratio, Effectiveness Ratio, Efficiency Ratio.

ABSTRAK : Pengertian dari kinerja keuangan suatu daerah adalah tingkat pencapaian suatu hasil kerja pada bidang keuangan daerah. Pengukuran kinerja keuangan Pemerintah Daerah dilakukan dengan meneliti Rasio Kinerja Keuangan Daerah yang dilihat melalui Laporan Realisasi APBD Kota Medan. Rasio-rasio untuk menilai kinerja keuangan pemerintah daerah yang digunakan dalam penelitian ini antara lain: Rasio Pertumbuhan, Rasio Efektifitas serta Efisiensi. Penelitian ini memiliki tujuan untuk menganalisis tingkat Rasio Pertumbuhan, Efektifitas dan Efisiensi selama periode 2016-2019 untuk melihat kinerja keuangan Pemerintah Kota Medan. Dalam penulisan skripsi ini menggunakan metode analisis deskriptif kuantitatif. Hasil dari penelitian ini menunjukkan kinerja keuangan Pemerintah Kota Medan dengan menggunakan Growth Ratio atau Rasio Pertumbuhan masih belum optimal karena terdapat penurunan yang signifikan pada tahun 2018 akibat penurunan pendapatan daerah di Kota Medan. Kinerja keuangan Kota Medan yang diukur dengan Rasio Efektivitas tahun 2016 dikategorikan cukup efektif yaitu 84,82\%. Pada tahun 2017, 2018, dan 2019 dikategorikan efektif karena memiliki nilai di atas 90\% yaitu 2017 sebesar 99,15\%, 2018 sebesar 92,88\%, dan pada tahun 2019 sebesar 90,56\%. Kinerja keuangan Pemerintahan Kota Medan yang diukur dengan Rasio Efisiensi dikategorikan sangat efisien karena seтиa hasil memiliki nilai di bawah 60\%. Tahun 2016 $10,35 \%, 20178,55 \%, 2018$ 7,35\%, 2019 9,61\%.

Kata Kunci : Growth Ratio, Rasio Efektivitas, Rasio Efisiensi.

\section{Pendahuluan}

Tujuan negara Indonesia sebagaimana dimaksud pada alenea keempat dalam Pembukaan Undang-Undang Dasar Negara Republik Indonesia Tahun 1945, yaitu melindungi segenap bangsa Indonesia dan seluruh darah Indonesia, serta memajukan kesejahteraan umum, mencerdaskan kehidupan bangsa, dan berperan serta. dalam melaksanakan tatanan dunia. Untuk mencapai 
tujuan bernegara diperlukan suatu sistem pengelolaan keuangan yang sesuai dengan isi Pembukaan UUD 1945 demi menjaga kelangsungan kedaulatan negara dan meningkatkan kemakmuran rakyat dengan kedaulatan dan kemakmuran rakyat. berdasarkan prinsip hukum. (Halim dan Maria, 2020).

Kinerja keuangan Pemerintah Daerah merupakan suatu pencapaian hasil dari pekerjaan pada fokus keuangan daerah yang terdiri dari pendapatan suatu daerah serta belanja daerah yang biasanya menggunakan sistem keuangan yang ditetapkan dari kebijakan atau ketentuan perundang-undangan dalam suatu atau beberapa periode anggaran. Bentuk dari kinerja keuangan yaitu berupa rasio keuangan yang dibentuk melalui unsur-unsur Laporan Pertanggungjawaban pemegang kekuasaan dalam suatu daerah berupa perhitungan APBD. (Agustina,2013)

Salah satu metodeyang digunakan penulis untuk mengukur kinerja keuangan Pemerintah Daerah dapat dilakukan dengan menggunakan Rasio Kinerja Keuangan pada Pemerintah Daerah yang dilihat dari Laporan Realisasi APBD Kota Medan. Penelitian ini hanya berfokus pada 3 Rasio Kinerja Keuangan Daerah.

Rasio Pertumbuhan atau Growth Ratio ialah salah satu rasio untuk melihat bagaimana kemampuan pemerintah daerah dalam satu atau beberapa periode anggaran yang berlangsung, apakah daerah tersebut berhasil atau tidak menumbuhkan pendapatan atau belanja daerahnya secara positif ataupun sebaliknya. Growth Ratio pada dasarnya mengukur keberhasilan pemerintah daerah dalam meningkatkan ataupun mempertahankan kinerja yang dicapai dalam kurun satu periode dibandingkan dengan periode sebelumnya. (Mahmudi,2019)

Rasio efektivitas merupakan rasio yang menunjukkan keberhasilan Pemerintah Daerah untuk mewujudkan pendapatan yang akan dicapai, yang selanjutnya akan disesuaikan dan dibandingkan dengan aturan target yang telah ditetapkan yang dilihat dari potensi riil daerah yang bersangkutan. Apabila tingkat keefektivitasan suatu daerah semakin meningkat maka hal tersebut menunjukkan bahwa kemampuan daerah tersebut semakin baik. (Halim, 2012)

Rasio Efisiensi merupakan salah satu rasio yang menunjukkan besar biaya yang akan maupun yang dikeluarkan pemerintah suatu daerah dalam memperoleh pendapatan daerahnya dengan melihat pendapatan yang akan diterima oleh daerah tersebut. Apabila rasio efisiensi keuangan suatu daerah semakin kecil, maka yang terjadi semakin baik pula kinerja keuangan daerah yang bersangkutan tersebut. (Mardiasmo, 2013)

\section{Landasan Teori \\ 2.1 UraianTeoritis}

\subsubsection{Teori Institusional}

Teori institusional atau teori institusional memiliki arti bahwa organisasi atau individu yang mengedepankan legitimasi memiliki lebih banyak upaya untuk menyesuaikan dengan ekspektasi internal maupun ekspektasi eksternal. Organisasi publik yang memiliki kecenderungan untuk memperoleh legitimasi yang lebih tinggi biasanya memiliki kesamaan dengan organisasi lain. (Scott, 2011)

\subsubsection{Teori Stakeholder}

Stakeholder theory digunakan atau dibuat untuk membantu dan mendukung pihak manajemen suatu perusahaan dalam upaya untuk meningkatkan terciptanya nilai sebagai bagian akibat dari berbagai kegiatan yang dilakukan untuk mengurangi kerugian yang mungkin timbul di kemudian hari bagi para pemangku kepentingan. (Devi, dkk, 2017)

\subsubsection{Teori Kinerja Keuangan Perusahaan}

Teori kinerja keuangan perusahaan mempunyai pengertian bahwa teknik analisis digunakan dalam perusahaan dalam melihat sebesarap jauh sebuah perusahaan apakah telah melakukan kinerja yang sesuai dengan aturan pelaksanaan keuangan yaitu dengan tepat dan benar. Salah satunya yaitu dengan cara membuat laporan keuangan perusahaan yang mengikuti ketentuan dan standar akuntansi keuangan. (Fahmi, 2012).

\subsubsection{Definisi Pengelolaan Keuangan Daerah}

Pengelolaan merupakan suatu istilah yang biasanya digunakan dalam ilmu manajemen, yaitu dari kata "mengelola" dan mengacu pada proses penanganan sesuatu untuk mencapai suatu tujuan. Keuangan daerah memiliki arti yang sangat besar dalam penyelenggaraan pemerintahan, serta kegiatan pembangunan yang dilakukan oleh masyarakat pelaksana pemerintahan di masing-masing daerah, sehingga keuangan pada suatu daerah 
diupayakan agar dapat berjalan dengan efisien serta efektif. (Santoso, Eko, 2011).

\subsubsection{Rasio Kinerja Keuangan Pemerintah Daerah}

Ada banyak cara yang digunakan untuk mengukur kinerja keuangan didalam suatu daerah, salah satunya ialah menggunakan rasio kinerja keuangan daerah, yaitu : Rasio Kemandirian, Rasio efektivitas, Rasio efisien, Rasio pertumbuhan dan Rasio belanja modal.

\subsubsection{Anggaran Pendapatan dan Belanja Daerah}

Anggaran Pendapatan Belanja Daerah merupakan rancangan dari suatu rencana dalam focus pekerjaan keuangan dan dibuat dengan tujuan untuk jangka waktu yang relatif lama, ketika DPRD atau badan legislatif memberikan wewenang berupa kredit kepada pihak eksekutif atau yang biasa disebut kepala daerah yang berwenang memiliki tujuan dalam pembiayaan rumah tangga dalam daerah tersebut. Hal tersebut harus sesuai dengan apa tang telah dirancang dan menjadi dasar ketika dianggarkan, untuk menunjukkan semua pendapatan dan menutupi semua biaya. (Halim, 2012).

\subsubsection{Growth Ratio}

Rasio Pertumbuhan merupakan rasio yang bertujuan untuk mengetahui apakah dalam suatu anggaran dalam satu atau beberapa periode yang bersangkutan, kinerja pemerintah daerah melalui kinerja keuangan APBDnya mengalami peningkatan pertumbuhan secara positif atau sebaliknya yaitu negatif. Apabila dimasa yang akan datang terjadi penurunan atau pertumbuhan negatif, maka hal tersebut merupakan suatu peringatan dan indikasi penurunan kinerja keuangan pada daerah yang bersangkutan. (Mahmudi, 2019)

Rasio Pertumbuhan

$=\frac{\text { Pendapatan tahun } t-\text { Pendapatan Tahun }(t-1)}{\text { Pendapatan tahun }(\mathrm{t}-1)}$

\subsubsection{Rasio Efektivitas}

Rasio efektivitas merupakan salah satu rasio yang digunakan untuk melihat kemampuan pemerintah dalam suatu daerah dalam mewujudkan realisasi pada pendapatan daerahnya sendiri kemudian selanjutnya akan dibagi dengan anggaran yang telah ditentukan dalam potensi nyata dalam suatu daerah. Pendapatan asli pada suatu daerah dapat dikatakan dengan kategori efektif jika hasil atau nilai yang dicapai 100 atau lebih dari $100 \%$. Dalam hal demikian dapat ditarik simpulan bahwa semakin besar nilai suatu pula rasio efektivitas maka semakin baik kinerja pemerintahnya. (Halim, 2012).

Rasio Efektivitas $=\frac{\text { Realisasi Pendapatan }}{\text { Anggaran Pendapatan }} \times 100 \%$

Tabel 1. Persentase Kinerja Efektivitas Keuangan

\begin{tabular}{|c|c|}
\hline $\begin{array}{c}\text { Persentase } \\
\text { Kinerja Keuangan }\end{array}$ & Kriteria \\
\hline $100 \%$ keatas & $\begin{array}{l}\text { Sangat } \\
\text { Efektif }\end{array}$ \\
\hline $90 \%-100 \%$ & Efektif \\
\hline $80 \%-90 \%$ & $\begin{array}{l}\text { Cukup } \\
\text { Efektif }\end{array}$ \\
\hline $60 \%-80 \%$ & $\begin{array}{l}\text { Kurang } \\
\text { Efektif }\end{array}$ \\
\hline Kurang dari $60 \%$ & Tidak Efektif \\
\hline
\end{tabular}

Sumber: Kepmendagri No. 690.900.327

\subsubsection{Rasio Efisiensi Keuangan Daerah}

Rasio efisiensi merupakan salah satu rasio yang menunjukkan kemampuan pemerintah daerah dengan melihat besarnya biaya yang direalisasikan dalam mengumpulkan pendapatan daerahnya yang selanjutnya akan dibandingkan dengan belanja daerahnya. Semakin kecil nilai dari rasio efisiensi akan berarti bahwa maka semakin baik pula kinerja pemerintah dalam suatu daerah. (Mardiasmo, 2013)

$$
\text { REKD }=\frac{\text { Realisasi Belanja Daerah }}{\text { Realisasi Pendapatan Daerah }} \times 100 \%
$$

\section{Tabel 2. Kriteria Pengukuran Efisiensi}

\begin{tabular}{|c|c|}
\hline $\begin{array}{c}\text { Kriteria } \\
\text { Efisiensi }(\%)\end{array}$ & $\begin{array}{c}\text { Persentasi } \\
\text { Efisiensi }\end{array}$ \\
\hline$>100 \%$ & Tidak Efisien \\
\hline $90-100 \%$ & Kurang Efisien \\
\hline $80-90 \%$ & Cukup Efisien \\
\hline $60-80 \%$ & Efisiensi \\
\hline$\leq 60 \%$ & Sangat Efisien \\
\hline
\end{tabular}

Sumber: Halim (2012)

\section{Metode Penelitian \\ 3.1. Jenis Penelitian}

Jenis dari data yang diperoleh dalam penelitian adalah jenis data kuantitatif, yaitu data-data yang dikumpulkan peneliti berupa angka-angka yang selanjutnya akan diolah dan dianalisis oleh penulis menggunakan teknik teknik perhitungan matematik. 


\subsection{Teknik Analisis Data}

Dalam penelitian ini, analisis data yang digunakan penulis adalah analisis deskriptif, yaitu metode yang bertujuan untuk mendeskripsikan fakta secara akurat dan jelas melalui pertimbangan Rasio Kinerja Keuangan Pemerintah Daerah Kota Medan.

\subsubsection{Growth Ratio}

"Rasio Pertumbuhan merupakan rasio yang bertujuan untuk mengetahui apakah dalam suatu anggaran dalam satu atau beberapa periode yang bersangkutan, kinerja pemerintah daerah melalui kinerja keuangan APBDnya mengalami peningkatan pertumbuhan secara positif atau sebaliknya. Jika terjadi penurunan atau pertumbuhan negatif, maka hal tersebut merupakan indikasi penurunan kinerja keuangan daerah yang bersangkutan". (Mahmudi, 2019).

\subsubsection{Rasio Efektivitas}

"Rasio efektivitas merupakan rasio yang menunjukkan kemampuan pemerintah daerah dalam mewujudkan pendapatan daerahnya sendiri yang akan dibandingkan dengan anggaran yang telah ditentukan dalam potensi riil suatu daerah. Pendapatan asli daerah efektif jika hasil atau nilai yang dicapai 100 atau lebih dari $100 \%$. Dengan demikian dapat ditarik kesimpulan bahwa semakin besar rasio efektivitas maka semakin baik kinerja pemerintah". (Halim, 2012)

\subsubsection{Rasio Efisiensi}

"Rasio efisiensi merupakan rasio yang menunjukkan rasio besarnya biaya yang dikeluarkan dalam hal perolehan pendapatan dengan realisasi pendapatan yang diterima oleh pemerintah daerah. Semakin kecil rasio efisiensi maka semakin baik kinerja pemerintah daerah". (Mardiasmo, 2013)

\section{Hasil Penelitian}

\subsection{Growth Ratio}

Tabel 3. Perhitungan Rasio Pertumbuhan Pemerintah Kota Medan

\begin{tabular}{|c|c|c|c|}
\hline Tahun & Pendapatan Tahun t & Pendapatan Tahun t-1 & $\begin{array}{c}\text { Pertumbuhan } \\
\text { Pendapatan }\end{array}$ \\
\hline 2016 & $1.135 .048 .520 .750,23$ & 1.002 .344 .427 .216 & $13,2 \%$ \\
\hline 2017 & 1.380 .349 .594 .488 & 1.135 .048 .520 .750 & $21,6 \%$ \\
\hline 2018 & 1.308 .458 .605 .694 & 1.380 .349 .594 .488 & $-5,2 \%$ \\
\hline 2019 & 1.463 .915 .001 .282 & 1.308 .458 .605 .694 & $11,8 \%$ \\
\hline \multicolumn{3}{|c|}{ Rata - rata } & $10,35 \%$ \\
\hline
\end{tabular}

Sumber : Data Olah (2021)

Terlihat bahwa untuk tahun 2016, 2017 dan 2019 laju pertumbuhan pendapatan daerah Kota Medan terjadi peningkatan yang cukup meningkat dari tahun ketahun, namun pada tahun 2018 pendapatan daerah terjadi penurunan yang cukup tajam karena pendapatan tahun tersebut tidak mengalami peningkatan namun sebaliknya, hal itu menyebabkan penurunan rasio pertumbuhan. Hal ini terjadi karena pendapatan yang diperoleh pada periode atau tahun yang bersangkutan tidak melebihi nilai pendapatan pada periode atau tahun sebelumnya karena adanya penurunan pendapatan dari pendapatan asli daerah Kota Medan.

\subsection{Rasio Efektivitas}

Tabel 4. Perhitungan Rasio Efektivitas Pemerintah Kota Medan

\begin{tabular}{|c|c|c|c|}
\hline Tahun & Realisasi Pendapatan PAD & $\begin{array}{c}\text { Anggaran Pendapatan } \\
\text { PAD }\end{array}$ & Rasio Efektivitas \\
\hline 2016 & 1.135 .048 .520 .750 & 1.338 .127 .546 .952 & $84,82 \%$ \\
\hline 2017 & 1.380 .349 .594 .488 & 1.392 .127 .546 .952 & $99,15 \%$ \\
\hline 2018 & 1.308 .458 .605 .694 & 1.408 .770 .116 .276 & $92,88 \%$ \\
\hline 2019 & 1.463 .915 .001 .282 & 1.616 .553 .386 .786 & $90,56 \%$ \\
\hline \multicolumn{3}{|c|}{ Rata - rata } & $91,85 \%$ \\
\hline
\end{tabular}

Sumber : Data Olah (2021) 
Pendapatan daerah cukup memuaskan yaitu pada tahun 2016 sebesar 84,82\% yang termasuk dalam nilai kategori yang cukup efektif. Pada tahun 2017 nilai efektivitas sebesar 99,15\% mengalami peningkatan sebesar $14,33 \%$ dari tahun 2016 dan menunjukkan kategori efektif karena adanya peningkatan realisasi anggaran Pendapatan Asli Daerah akibat meningkatnya partisipasi masyarakat dalam membayar pajak dan retribusi. Pada tahun 2018 rasio efektivitas sebesar $92,88 \%$ menurun $6,27 \%$ dari tahun sebelumnya, namun masih menunjukkan kategori efektif. Pada tahun 2019 rasio efektivitas sebesar $90,56 \%$ menurun $2,32 \%$ dari tahun sebelumnya, namun masih termasuk dalam kategori efektif.

. Jika dilihat dari tahun 2016 hingga 2019 kinerja pemerintah daerah mengalami peningkatan dan termasuk dalam kategori efektif yaitu dengan rata-rata $91,85 \%$ yang berarti kinerja keuangan dalam kondisi baik.

\subsection{Rasio Efisiensi}

Tabel 5. Perhitungan Rasio Efisiensi Pemerintah Kota Medan

\begin{tabular}{|c|c|c|c|}
\hline Tahun & Realisasi Belanja Daerah & $\begin{array}{c}\text { Realisasi Pendapatan } \\
\text { Daerah }\end{array}$ & Rasio Efisiensi \\
\hline 2016 & 117.510 .800 .285 & 1.135 .048 .520 .750 & $10,35 \%$ \\
\hline 2017 & 118.100 .062 .550 & 1.380 .349 .594 .488 & $8,55 \%$ \\
\hline 2018 & 96.178 .200 .441 & 1.308 .458 .605 .694 & $7,35 \%$ \\
\hline 2019 & 140.687 .858 .004 & 1.463 .915 .001 .282 & $9,61 \%$ \\
\hline \multicolumn{3}{|c|}{ Rata - rata } & $8,96 \%$ \\
\hline
\end{tabular}

Sumber : Data Olah (2021)

Berdasarkan tabel di atas maka perhitungan rasio efisiensi keuangan daerah Kota Medan tahun 2016 memiliki nilai $10,35 \%$ yang termasuk dalam kategori sangat efisien. Pada tahun 2017 rasio efisiensi Kota Medan sebesar $8,55 \%$ meningkat $1,8 \%$ dari periode sebelumnya yang termasuk dalam kategori sangat efisien karena biaya yang dikeluarkan oleh Pemerintah Daerah Kota Medan untuk mengumpulkan PAD semakin kecil dan realisasi pendapatan asli daerahnya. meningkat setiap tahun. tahun 2018 rasio efisiensi Kota Medan sebesar 7,35\%, kembali meningkat sebesar 1,2\% dari tahun 2017 dan meningkat sebesar 3\% dari tahun 2016 yang termasuk kategori sangat efisien. Pada tahun 2019 rasio efisiensi keuangan daerah Kota Medan sebesar $9,61 \%$ turun $2,26 \%$ dari tahun sebelumnya, namun masih termasuk dalam kategori sangat efisien.

Rasio efisiensi keuangan daerah Kota Medan dari tahun 2016 hingga 2018 mengalami kenaikan yang sangat baik setiap tahunnya. Namun untuk tahun 2019 terjadi penurunan sebesar 2,26\% namun masih dalam kategori sangat efisien.

\section{Kesimpulan}

Berdasarkan hasil dari analisa kinerja keuangan Pemerintah Daerah Kota Medan dilihat dari hasil penelitian yang dilakukan dan diukur melalui rasio kinerja dari keuangan daerah, maka sebagai berikut:

1) Kinerja keuangan Pemerintah Daerah Kota Medan yang diukur dengan Growth Ratio atau rasio pertumbuhan masih belum maksimal karena adanya penurunan yang cukup signifikan pada tahun 2018 akibat penurunan pendapatan daerah di Kota Medan.

2) Kinerja dari keuangan Pemerintah Kota Medan yang diukur dengan Rasio Efektivitas tahun 2016 dikategorikan cukup efektif yaitu 84,82\%. Pada tahun 2017, 2018, dan 2019 dikategorikan efektif karena memiliki nilai diatas $90 \%$ yaitu pada tahun 2017 sebesar 99,15\%, pada tahun 2018 sebesar 92,88\%, dan pada tahun 2019 sebesar 90,56\%.

3) Kinerja keuangan Pemerintah Kota Medan yang diukur dengan Rasio Efisiensi dikategorikan sangat efisien karena semua hasil menunjukkan nilai dibawah $60 \%$. Tahun 2016 10,35\%, 2017 8,55\%, 2018 7,35\%, $20199,61 \%$.

\section{DAFTAR PUSTAKA}

Agustina, Oesi, (2013). Jurnal Analisis Kinerja Pengelolaan Keuangan Daerah dan Tingkat Kemandirian Daerah Di Era Otonomi Daerah: Studi Kasus Kota Malang (Tahun Anggaran 2007-2011). Jurusan Ilmu 
Ekonomi, Fakultas Ekonomi dan Bisnis, Universitas Brawijaya

Devi, Bunga Ekawati, dkk. (2017). Pengaruh Intellectual Capital Terhadap Kierja Keuangan Perusahaan. Jurnal ISSN: 23559357. Vol. 4 No.1, Universitas Telkom.

Fahmi, Irham. (2012). Analisis Kinerja Keuangan. Penerbit Alfabeta : Bandung.

Halim, Abdul dan Maria Evi. (2020). Problematika Hukum Dalam Pengelolaan Keuangan Negara \& Daerah. Penerbit Sekolah Tinggi Ilmu Manajemen Yayasan Keluarga Pahlawan Negara : Yogyakarta.

Halim, Abdul. (2012). Akuntansi Sektor Publik, Akuntansi Keuangan Daerah. Edisi 4. Penerbit Salemba Empat : Jakarta.

Mahmudi. (2019). Manajemen Kinerja Sektor Publik. Edisi Ketiga. Penerbit Sekolah
Tinggi Ilmu Manajemen Yayasan Keluarga Pahlawan Negara : Yogyakarta.

Mardiasmo. (2013). Perpajakan Edisi Revisi. Penerbit Andi : Yogyakarta.

Santoso, Eko. (2011). Efisiensi Dan Efektifitas Pengelolaan Keuangan Daerah Di Kabupaten Ngawi. Tesis Magister Ekonomi Dan Studi Pembangunan : Universitas Sebelas Maret, Surakarta.

Scott, William R. (2011). Financial Accounting Theory. Edisi Keenam. Penerbit Person Prentice Hall: Canada.

Mahmudi. (2019). Manajemen Kinerja Sektor Publik. Edisi Ketiga. Penerbit Sekolah Tinggi Ilmu Manajemen Yayasan Keluarga Pahlawan Negara : Yogyakarta. 